\title{
Papermaking as Potential Use of Fibers from Mexican Opuntia ficus-indica Waste
}

\author{
Elaboración de papel como uso potencial de fibras a partir de desechos de Opuntia ficus-indica
}

\begin{abstract}
Citlali Colín-Chávez ${ }^{\mathrm{a*}}$, Herlinda Soto-Valdez ${ }^{\mathrm{b}}$, José Turrado-Saucedoc, Armida Rodríguez-Félix ${ }^{\mathrm{b}}$, Elizabeth Peralta ${ }^{\mathrm{b}}$, Alma Rosa Saucedo-Coronac, Marcela Guzmán-Coronad

a CONACYT- Centro de Investigación en Alimentación y Desarrollo, A.C. -CIDAM Kilómetro $8 \mathrm{~s} / \mathrm{n}$, Antigua carretera a Pátzcuaro, C.P. 58341. Morelia, Michoacán, México.

b Centro de Investigación en Alimentación y Desarrollo, A.C. CTAOV. Carretera Gustavo Enrique Astiazarán Rosas, No. 46. Col. La Victoria, C.P. 83304, Hermosillo, Sonora, México.

Departamento de Madera, Celulosa y Papel, Centro Universitario de Ciencias Exactas e Ingeniería, Universidad de Guadalajara. Kilómetro 15.5, Carretera Guadalajara-Nogales, Las Agujas, C.P. 45010, Zapopan, Jalisco, México.

d Instituto Tecnológico José Mario Molina Pasquel y Henríquez. Libramiento Chapala-Ajijic, No 200, C.P. 45900. Chapala, Jalisco, México.
\end{abstract}

\section{ABSTRACT}

The papermaking potential of Opuntia ficus-indica (OFI) waste fibers was studied in this research. Alpha cellulose, lignin, hollocellulose, ethanol/benzene extractives and ash content were determined as $53.7 \pm 0.1 \%, 2.4 \pm 0.3 \%$, $61.6 \pm 5.7 \%, 7.1 \pm 0.3 \%$ and $26.4 \pm 0.1 \%$, respectively. The average fiber length, width, lumen, and cell wall thickness were found to be $1.1 \pm 0.3 \mathrm{~mm}, 18.8 \pm 6.1 \mu \mathrm{m}, 12.1 \pm 5.4 \mu \mathrm{m}$, and $4.3 \pm 1.0 \mu \mathrm{m}$. Soda pulping was conducted using 20 and $28 \%$ sodium hydroxide, cooking temperatures of 160 and $175^{\circ} \mathrm{C}$, cooking times of 60 and $120 \mathrm{~min}$, and liquor- to fiber ratio of 9:1. Soda pulping with $28 \%$ sodium hydroxide, $175^{\circ} \mathrm{C}$ and 120 min showed a lower Kappa number of $29.60 \pm 1.7$ and a total yield of $32.2 \pm 1.6 \%$. In general, tensile strength index $(36.0 \pm 5.0 \mathrm{Nm} / \mathrm{g})$, stretch $(1.7 \pm 0.3 \%)$, breaking length $(3.7 \pm 0.5$ $\mathrm{km})$, burst index $\left(3.2 \pm 0.4 \mathrm{KPa} . \mathrm{m}^{2} / \mathrm{g}\right)$, tear index $(7.3 \pm 0.0$ $\mathrm{mN} \cdot \mathrm{m}^{2} / \mathrm{g}$ ), folding endurance (166 times) and porosity (> 120 s) of OFI pulp were comparable with wood and non-wood pulps.

Keywords: Opuntia ficus-indica waste, Fiber morphology, Pulp properties, Paper properties, Non-wood paper.

\section{RESUMEN}

En esta investigación se estudió el potencial del uso de desechos de fibras de Opuntia ficus-indica (OFI) para elaborar papel. La estrategia metodológica que se siguió fue: caracterización de materia prima, análisis morfológico de las fibras, pulpeo soda mediante un diseño completamente al azar con un arreglo factorial $2^{3}$, refinación de pulpa, formación y caracterización de hojas. El contenido de alfa-celulosa, lignina, holocelulosa, extractivos en etanol/benceno y cenizas fue de $53.7 \pm 0.1 \%, 2.4 \pm 0.3 \%, 61.6 \pm 5.7 \%, 7.1 \pm 0.3 \%$ y $26.4 \pm 0.1 \%$, respectivamente. El promedio de la longitud de las fibras, ancho, lumen y espesor de la pared celular fue $1.1 \pm 0.3 \mathrm{~mm}$, $18.8 \pm 6.1 \mu \mathrm{m}, 12.1 \pm 5.4 \mu \mathrm{m}, 4.3 \pm 1.0 \mu \mathrm{m}$. Las condiciones de pulpeo fueron: 20 y $28 \%$ de hidróxido de sodio, 160 y 175 ${ }^{\circ} \mathrm{C}$, durante 60 y $120 \mathrm{~min}$ y una relación licor/fibra de 9:1. El proceso de pulpeo con $28 \%$ de hidróxido de sodio, $175^{\circ} \mathrm{C}$ y 120 min mostró un menor número de Kappa $(29.60 \pm 1.7)$ y un rendimiento total de $32.2 \pm 1.6 \%$. En general el índice de tensión $(36.0 \pm 5.0 \mathrm{Nm} / \mathrm{g})$, deformación $(1.7 \pm 0.3 \%)$, longitud de ruptura $(3.7 \pm 0.5 \mathrm{~km})$, índice de estallido $(3.2 \pm 0.4 \mathrm{KPa}$. $\left.\mathrm{m}^{2} / \mathrm{g}\right)$, índice de rasgado $\left(7.3 \pm 0.0 \mathrm{mN} \cdot \mathrm{m}^{2} / \mathrm{g}\right)$, resistencia al doblez (166 times) y porosidad (> $120 \mathrm{~s}$ ) de la pulpa obtenida fueron comparables con valores reportados para pulpa de fibras maderables y no maderables.

Palabras clave: Desecho de Opuntia ficus-indica, Morfología de las fibras, Propiedades de la pulpa, Propiedades de papel, Papel de fibras no maderables.

\section{INTRODUCCIÓN}

Nowadays, there is a trend to substitute single-use plastic packaging for environmental-friendly packaging due to the growing awareness of the environmental damages associated (Herbes et al., 2018). Paper and paperboard are tagged as environmental-friendly packaging and can substitute several kinds of plastic.

In 2016, the world production of paper and paperboard was 409 million tons (FAO, 2016). The paper industry is also associated with environmental problems because of its high energy consumption and emissions, high consumption of chemicals and it is a sector with highly intensive use of natural resources, like wood, non-wood fibers, and water (Wang et al., 2016; IEA, 2017; Man et al., 2018; Sun et al., 2018). The environmental problems related to raw materials for the paper industry require search and study of diverse alternatives that mitigate their effects. The principal natural resource used to produce paper is pulp fibers, which can be obtained from wastepaper pulp, wood pulp and pulp from other fibers. The use of wood to produce paper has caused a great deforestation problem. As a result, in recent years, several research groups have investigated the technical viability of using pulp derived from agro-industry waste, straw, bagasse and other non-wood fibers (Rainey and Covey, 2016; 
Gonzalo et al., 2017; Kaur et al., 2017). Commercially, pulps derived from straw, bagasse, bamboo, esparto, reeds, grass, flax and hemp are used for paper production (FAO, 2017). The viability for the use of non-wood fibers as a raw material for papermaking will depend on the chemical and morphological properties of the fibers, as well as the availability of this resource, its proximity to the paper factories and, as it has recently been emphasized, the amount of water used during the crop irrigation process (Man et al., 2018). Therefore, it is necessary to continue exploring the use of other non-wood fibers as a raw material for papermaking.

In Mexico, arid and semi-arid lands constitute $49.20 \%$ of the national territory. Mexico is also considered one of the main diversity centers of cacti. In fact, there are 586 species of cacti and the highest number of native species in Mexico (Ortega-Baes et al., 2010). The cacti of greatest economic importance in the world are the Opuntia spp., commonly named "nopales" in Mexico (Inglese et al., 2018). The economic importance of nopales resides in its nutritional value, functional and therapeutic properties, and its potential use in the cosmetics and bioenergy industries (Ciriminna et al., 2019). The worldwide-cultivated species of Opuntia genus is Opuntia ficus-indica (OFI). Opuntia spp. are characterized by growing in extreme temperature conditions (-10 to 70 ${ }^{\circ} \mathrm{C}$ ) and scarce water availability $(50 \mathrm{~mm}$ or less annual precipitation) (Nobel and Bobich, 2002; Ginestra et al., 2009; Inglese et al., 2018). They also need 20 to 30 days to develop a harvestable size and they have very low lignin content (3.6 to $16 \%$ ) (Rodriguez-Felix and Cantwell, 1988; Malainine et al., 2003). Mexico has a great availability of wild (83) and cultivated (4) species of OFI (Guzmán et al., 2003). The cultivated area of nopales in Mexico is around 77,878 ha (SIAP 2017). Actually, there is a big interest to valorize nopales, for example, it has been used as biofuel feedstocks and coagulant in wastewater bioremediation (Vishali and Karthikeyan, 2015; Yang et al., 2015; Barbera and Gurnari, 2018). The production of nopales for foodstuff uses generates wastes at agricultural and industrial levels, for example, in Mexico City, each year dethorning process of nopal generates around 40,000 tons of waste (Marin-Bustamante et al., 2017). This can become a focus of contamination (insects and microorganisms). Recently, several publications reveal the possible applications of nopales in science and materials engineering. About this, three research topics were identified: I) Activated charcoal production from OFI (Ouhammou et al., 2017), II) OFI as polymer matrix reinforcement (Malainine et al., 2004; Malainine et al., 2005; Greco et al., 2013; Greco and Maffezzoli, 2015) and III) OFI as raw material for papermaking (Mannai et al., 2016; Mannai et al., 2018). The last topic will be explored in this study. It is important to mention that during the construction of the theoretical framework of this research, only two papers about this topic were found. Tunisian OFI fibers have high cellulose (53\%) and low lignin (4.8\%) content with long and thick fibers. The Tunisian fibers have chemical and morphological characteristics favorable for papermaking. OFI pulp was obtained by two methods, soda-hydrogen peroxide ( $80.8 \%$ of yield) and soda-anthraquinone $(41.1 \%$ of yield) process. The paper sheets obtained, by both methods, had acceptable physical properties. In agreement with this data, OFI fibers can be used as raw material for papermaking (Mannai et al., 2016; Mannai et al., 2018). However, it is necessary to continue exploring the properties of OFI fibers from other regions and other processes.

The aim of the present work was to explore an alternative for processing Mexican Opuntia ficus-indica waste to produce paper as a strategy for further valorization. Chemical characterization of the raw material was conducted and the morphological analysis of the fibers. Optimal parameters of the paper preparation procedure based on the soda process were established. Finally, laboratory paper sheets were manufactured and subjected to mechanical testing.

\section{MATERIALS AND METHODS Raw material}

OFI waste cladodes were obtained from a commercial cultivation area in La Victoria, Hermosillo, Sonora (México). OFI waste cladodes did not have quality for food consumption or processing. The cladodes were two years old and $89.23 \%$ moisture content. The cladodes size was $41.8 \pm 7.5 \mathrm{~cm}$ in length, $14.7 \pm 2.7 \mathrm{~cm}$ in width, and $797.0 \pm 287.8 \mathrm{~g}$ in weight.

\section{Preparation of raw material}

Cladodes were shredded to reduce the particle size and be ready to be ground by a hammer mill (own design) equipped with two different screen sizes (10.82 and 3.16 $\mathrm{mm}$ ). The ground material was fully washed with water, and sundried to constant moisture. Finally, fibers bundles were manually selected and stored at $20^{\circ} \mathrm{C}$.

\section{Characterization of the raw material}

Chemical properties of cladodes were determined in accordance with TAPPI standards for different components such as moisture (TAPPI 412 om-02), lignin (TAPPI 222 om15), a-cellulose (TAPPI $203 \mathrm{~cm}$-09), water-soluble (TAPPI 207 om-08), 1\% NaOH soluble (TAPPI 212 om-18), extractives (TAPPI 204 om-17), and ashes (TAPPI 211 om-16). Holocellulose was quantified according to Mannai et al. (2018).

\section{Morphological studies}

The fibers morphology was characterized according to TAPPI 259 om- 16 . Previously, fibers were treated with $28 \%$ $\mathrm{NaOH}$ at $176-199^{\circ} \mathrm{C}$ for $1 \mathrm{~h}$ under constant stirring to remove the cellular content. Characteristics of fibers, including length $(L)$, diameter $(D)$, wall thickness $(W)$, and lumen width (I) were measured with an optical microscope (DMR Leica, Wetzlar, HE, Germany). Additionally, the Runkel ratio (2W/l), flexibility coefficient (I/D), slenderness coefficient (L/D), and stiffness coefficient (2W/D) were obtained (Ogbonnaya et al., 1997; Ververis et al., 2004).

\section{Pulping}

Fibers were cooked with $\mathrm{NaOH}$ in a $1 \mathrm{~L}$ laboratory scale, oil heated, and cylindrical batch reactor (own design). 
The cylindrical reactor containing fibers, was introduced in the oil bath when the temperature was $80^{\circ} \mathrm{C}$. The time to reach cooking temperatures was 1 hour after which, it was kept constant. Cooking conditions were as stated in Table 1. The cooked material was filtered (325 mesh) and washed to remove the wastewater.

Table 1. Cooking conditions for OFI waste fibers pulping.

Tabla 1. Condiciones de cocción para la pulpa de fibras de desecho de OFI.

\begin{tabular}{lcc}
\hline Parameter & Low value & High value \\
\hline OFl fiber weight, $g$ & \multicolumn{2}{c}{$34.10 \pm 0.23$} \\
Liquid/solid ratio & \multicolumn{2}{c}{$9 / 1$} \\
Active alkali $(\mathrm{NaOH}), \%$ & 20 & 28 \\
Temperature, $^{\circ} \mathrm{C}$ & 160 & 175 \\
\hline Time, min & 60 & 120 \\
\hline
\end{tabular}

\section{Pulp beating}

The pulp was beaten in a Jokro-Muhle refiner (P.J \& Söhne Gmbh, Düren, NW, Germany) at 150 rpm for 25 min. Next, the pulp was screened using a $0.15 \mathrm{~mm}$ aperture size sieve (Lorentzen and Wettre, Kista, STO, Sweden) to remove the uncooked material and to evaluate the screened and rejected yield. Additionally, total yield was calculated by adding accepted and rejected yields according to TAPPI 274 $\mathrm{sp}-13$. Kappa number of the pulp was determined according to TAPPI 236 om-13.

\section{Paper sheets formation and characterization}

OFI waste paper sheets were prepared with a sheet former used according to TAPPI 205 sp-18. The tensile index according to TAPPI $494 \mathrm{om}-13$, burst index in accordance to TAPPI $403 \mathrm{om}-16$, tear index consistent to TAPPI $414 \mathrm{om}$ 12 , breaking length and stretch in accordance to TAPPI 494 om-13, folding consistent to TAPPI 423 om-16 and porosity according to TAPPI 460 om 16 were determined.

\section{Statistical analysis}

For cooking conditions optimization, a completely randomized design with a $2^{3}$ factorial arrangement was used. The factors were temperature $\left(160\right.$ and $\left.175^{\circ} \mathrm{C}\right)$, reaction time (60 and $120 \mathrm{~min}$ ), and active alkali (20 and 28\%), while the response variables were screening yield, rejects, total yield, and Kappa number. For paper sheet characterization, descriptive statistics and simple linear regression analyses were used.

\section{RESULTS AND DISCUSSION Characterization of the raw material}

Figure 1 shows the chemical composition of OFI waste. The content of lignin in OF/ waste is $2.4 \pm 0.3 \%$, much lower than values reported for any wood and non-wood material used for papermaking. In general, non-wood plants have less lignin than woods. Our results exhibit that lignin content was in the range $(2.51-4.80 \%)$ reported for OFI cladodes (Malainine et al., 2003; Mannai et al., 2016; Cheikh Rouhou et al., 2018). In addition, our results showed that OFI waste cladodes has only $8.30,18.0$, and $10.04 \%$ of lignin, that other authors reported for chili paper residue, rice straw, sugarcane bagasse, respectively (Gonzalo et al., 2017; Mulyantara et al., 2017; Kaur et al., 2018). The low lignin content is convenient since one of the principal targets in the pulping process is the elimination of lignin from the fibers. OF/ waste had a holoceIlulose content of $61.6 \%$, value also close to that reported for OF/ trunks (64.5\%) and rice straw (60.7\%), but lower than that reported for chili paper residue (88.0\%) and sugarcane bagasse (76.7\%) (Rodríguez et al., 2008; Zhao et al., 2008; Mannai et al., 2016; Gonzalo et al., 2017). The OF/ waste cellulose content was $53.7 \pm 1.0 \%$, very similar to that reported for OFI trunks $(53.6 \%)$ and miscanthus residue $(51.0 \%)$, higher than the reported for rice straw (41.2\%), and lower than that reported for sugarcane bagasse (44.9\%) (Zhao et al., 2008; Rodríguez et al., 2010; Gonzalo et al., 2017; Mannai et al., 2018). Our results contrast with the $21.60 \%$ published by Malainine et al. (2003) and the $26.70 \%$ published by Cheikh Rouhou et al. (2018) for OFI cladodes. This apparent lack of agreement can be attributed to the season and age of the plants and edaphic factors at the cultivation sites. The ethanol-benzene extractables content in the $O F /$ waste cladodes was $7.10 \pm 0.3 \%$. This value is very close to that reported for OFI trunks (9.8\%) but higher than the published data for sugarcane bagasse (3.2\%), and chili paper residue (2.2\%) (Zhao et al., 2008; Mannai et al., 2016; Gonzalo et al., 2017; Cheikh Rouhou et al., 2018). In agreement with this result, some OF/ waste cladodes components will precipitate upon pulping and leave stains in the resulting paper sheets (Rodríguez et al., 2008). Cladodes contain different compounds that can be considered extractables. These compounds include chlorophyll, flavonoids like kaempferol, quercetin, methyl-3-kaempferol, kaempferol 3-methyl ether, quercetin 3-methyl ether, narcissin, (+)-dihydrokaempferol, (+)-dihydroquercetin and eriodictyol; terpenoids like (6S, 9S)-3-oxo-a-ionol- $\beta$-D-glucopyranoside and corchoionoside $\mathrm{C}$; carotenoids like cryptoxanthin, $\beta$-carotene and lutein (Jaramillo-Flores et al., 2003; Lee et al., 2003; Stintzing and Carle,

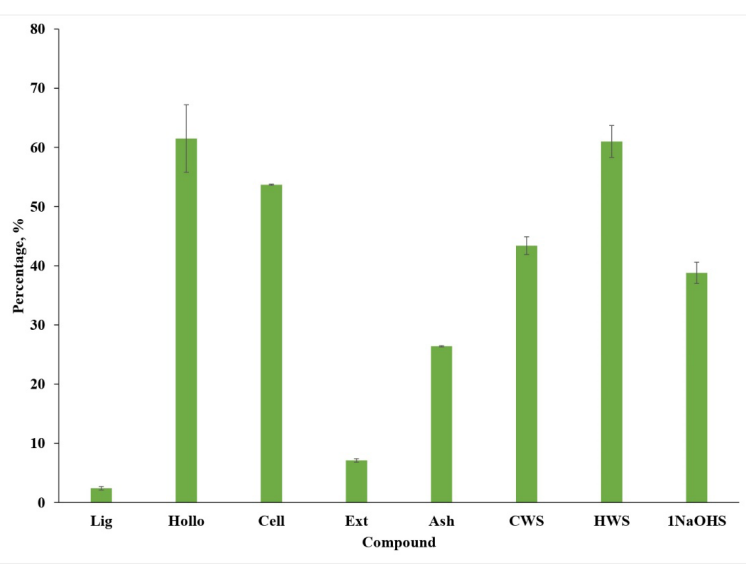

Fig. 1 Chemical characterization of Opuntia ficus-indica. Lig: lignin; Hollo: hollocelulose; Cell: $\alpha$-cellulose: Ext: extractives; CWS: cold-water solubles; HWS: hot water solubles; $1 \mathrm{NaOHS}: 1 \% \mathrm{NaOH}$ solubles.

Fig. 1. Caracterización química de Opuntia ficus-indica. Lig: lignina; Hollo: hollocelulosa; Célula: $\alpha$-celulosa: Ext: extractivos; CWS: solubles en agua fría; HWS: solubles en agua caliente; $1 \mathrm{NaOHS}$ : solubles en $\mathrm{NaOH}$ al $1 \%$. 
2005). Additionally, some pyrones (opuntioside l, opuntioside II, opuntioside III, 4-eyhoxyl-6-hydroxymethyl-apyrone,7-O$\beta$-D-glucopyranosyl-( $\rightarrow 4$ )- $\beta$-D-glucopyranoside) and fatty acids have been extracted from other Opuntias (Qiu et al., 2002; Qiu et al., 2007).

The cladodes ashes content was $26.4 \pm 0.1 \%$, close to the $23.31 \%$ reported for Cheikh Rouhou et al. (2018) a little higher than $19.60 \%$ reported by Malainine et al. (2003) and higher than the $5.50 \%$ reported by Mannai et al. (2018) for OFI. This result can be attributed to the presence of different minerals such as calcium, potassium, iron, and magnesium, being the most abundant calcium oxalate, which is waterinsoluble (Stintzing and Carle, 2005; Rodríguez-Garcia et al., 2007). In fact, it is higher than the value reported for wood and non-wood materials used for papermaking. The content of substances soluble in hot water in OFI waste cladodes was $61.0 \pm 2.7 \%$, higher than the reported for the same species of genus Opuntia (25\%-cladodes and 36.3\%-trunks), eucalyptus, sugarcane bagasse, cotton stalks, and rice straw (Jiménez et al., 2007; Rodríguez et al., 2008; Mannai et al., 2016; Mannai et al., 2018). This property indicates that different components of cladodes such as inorganic compounds, tannins, gums, sugars, and starches will be drawn with hot water. Finally, $1 \% \mathrm{NaOH}$ solution extracted low molecular weight carbohydrates of $\mathrm{OFI}$ waste cladodes. The content of substances soluble in $1 \% \mathrm{NaOH}$ was $38.8 \pm 1.80$. This value is higher than the $29.6 \%$ reported for OFI trunks (Mannai 2016). Zhong et al. (2010) and Majdoub et al. (2001) reported arabinose, galactose, galacturonic acid, glucose, glucuronic acid, xylose, rhamnose, uronic acid like low molecular weight carbohydrates in OFI cladodes.

In sum, the chemical properties of OF/ waste cladodes showed the suitability of this raw material as a non-wood source for papermaking.

\section{Morphological studies}

Figure 2 shows an OFI waste fiber and Table 2 its morphological characteristics. The size for these fibers was: length $1.1 \pm 0.3 \mathrm{~mm}$, diameter $18.80 \pm 6.1 \mu \mathrm{m}$, wall thickness $4.30 \pm 1.0 \mu \mathrm{m}$, and lumen width $12.10 \pm 5.4 \mu \mathrm{m}$. In general, the OFI waste fibers are longer than the data published for other Opuntia species. Gibson (1977) reported that the size for Opuntia species falls in the range of 629 to $330 \mu \mathrm{m}$ in length, 38.3 to $16.20 \mu \mathrm{m}$ in diameter, and 5.50 to $2.60 \mu \mathrm{m}$ in wall thickness. The length of the OFI waste fibers is higher than the reported for OFI cladodes fibers $(0.74 \mu \mathrm{m})$ and OFI trunks fibers $(0.76 \mu \mathrm{m})$ (Mannai et al., 2016; Mannai et al., 2018). Fiber length of OFI waste is in the range of hardwoods $(0.7-1.5 \mathrm{~mm})$ and within the range $(1.0-2.5 \mathrm{~mm})$ of non-wood fibers such as sugarcane bagasse, rapeseed straw, kenaf and sunflower stalk. The length of OFI waste fibers was similar to that of rapeseed straw, sunflower stalk and eucalyptus, but smaller than sugarcane bagasse, kenaf and pine fibers (Ashori et al., 2006; Khristova et al., 2006; Mazhari Mousavi et al., 2013; Gominho et al., 2014; Gulsoy and Ozturk, 2015; Rudi et al., 2016). Fibers with low $(<1)$ Runkel ratio are assessed to be efficient for sheet formation by the combination effect of

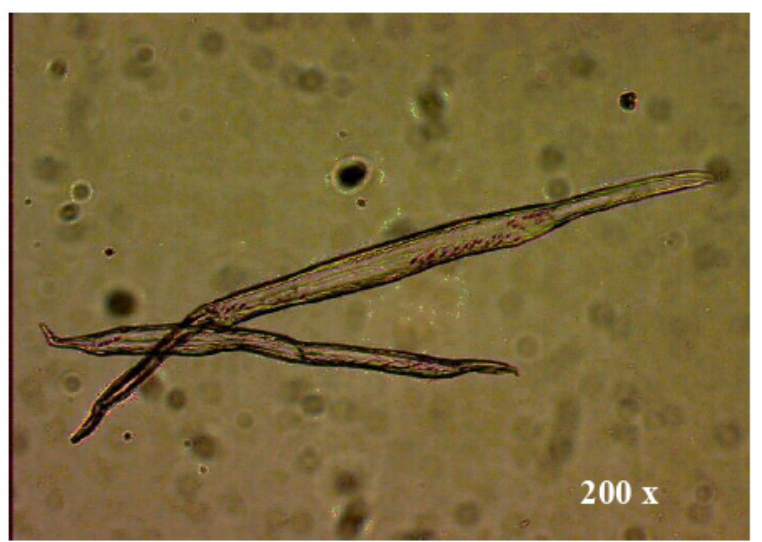

Figure 2. Opuntia ficus-indica fibers.

Figura 2. Fibras de Opuntia ficus-indica.

Table 2. Morphological characteristics of OFI waste fibers.

Tabla 2. Características morfológicas de las fibras de desecho de OFI.

\begin{tabular}{lc}
\hline Parameter & Value \\
\hline Fiber length, $\mathrm{mm}$ & $1.1 \pm 0.3$ \\
\hline Fiber diameter, $\mu \mathrm{m}$ & $18.8 \pm 6.1$ \\
\hline Fiber lumen width, $\mu \mathrm{m}$ & $12.1 \pm 5.4$ \\
\hline Fiber wall thickness, $\mu \mathrm{m}$ & $4.3 \pm 1.0$ \\
Elasticity coefficient & $0.60 \pm 0.11$ \\
Slenderness coefficient & $60.9 \pm 17.8$ \\
\hline Runkel ratio & $0.80 \pm 0.44$ \\
\hline
\end{tabular}

OFI results are presented as mean \pm SD of seven replicates.

thin walls and wide lumen. On the other hand, fibers with high Runkel ratio $(>1)$ are considered not to be efficient for sheet formation because these are indicative of tubular and noncollapsible fibers, providing a low bonding area (Villar et al., 2009). In agreement with the obtained Runkel ratio for OFI waste fibers $(0.80 \pm 0.44)$, these are suitable as raw material for papermaking.

According to the flexibility ratio, there are four groups of fibers (San et al., 2016): I) High elastic fibers with an elasticity ratio $>75$, II) Elastic fibers with an elasticity ratio between $55-75$, III) Rigid fibers with an elasticity ratio between 30-50, and IV) Highly rigid fibers with an elasticity ratio $<30$. The flexibility ratio of OFI fibers was found to be $0.60 \pm 0.11$; therefore, these are elastic fibers. The flexibility ratio shows the degree of fiber bonding in paper sheet (Anupam et al., 2016). Because OFI fibers have efficient elasticity, they are suitable for paper production. The slenderness ratio shows the fibers ability to bond with each other. If fibers have a high slenderness ratio, then these can collapse easily resulting in good surface contact and inter-fiber bonding during the formation of paper. The recommendable slenderness ratio for fibers to papermaking is $>30$. Along with the slenderness ratio (60.9 \pm 17.8$)$, OFI waste fibers are suitable to make paper.

In summary, anatomical ratios of OFI waste fibers show the suitability of these as a non-wood source for papermaking. 


\section{Pulp analysis}

Figure 3 presents the general process of OFI waste fibers pulping, and Table 3 shows the cooking conditions and pulp properties obtained from OFI waste fibers. The screening yields were in the range of 14.0 to $41.8 \%$ and time and $\% \mathrm{NaOH}$ showed statistically significant differences ( $\mathrm{p}$ $\leq 0.05$ ) on this property. This variable was inversely proportional to reaction time. Surprisingly, even when OFI waste cladodes contain low levels of lignin, the pulp yield was directly proportional to $\% \mathrm{NaOH}$. This behavior should be more attributed to the composition of the lignin itself than to its concentration. The exact proportion of syringyl, guaiacyl and p-hydroxyphenyl units of lignin in OFI fibers has not been reported. However, considering our results, we can hypothesize that the guaiacyl units are in a greater proportion in the lignin of OFI waste fibers because these structures are more difficult to hydrolyze during the alkaline pulping. Guaiacyl units have one methoxyl group and a free carbon-5 available for carbon-carbon inter-unit bonds, which make them resistant to lignin depolymerization in pulping. In contrast, siryngyl units are relatively unbranched and have a lower degree of condensation and therefore are easier to delignify (Del Río et al., 2007).

From all the pulping conditions, treatments 2 and 6 applied the lowest level of time and the highest level of \% $\mathrm{NaOH}$ giving screening yields of 41.8 and $36.3 \%$, respectively. However, the pulps delignification degree obtained with these treatments was not enough. Rejects values ranged between 0.1 and $29.5 \%$. According to this variable, the samples were grouped in two categories. In the first, the rejects were up to $21.0 \%$ and the pulps obtained with the treatments 1,3 , 4, 5 and 7 classified in this category. In the second category, the rejects were lower than $0.2 \%$ and the pulps obtained with the treatments 2, 6 and 8 classified here. Pulps obtained from treatments 2 and 6 showed the highest pulping yield but did not have an adequate delignification. The total yield for OFI waste pulp was in the range of 32.2 to $45.0 \%$. These values are in the range of yields reported for non-wood species such as rice straw, Leucaena, and morning glory (Dutt et al., 2004; López et al., 2008; Rodríguez et al., 2008).
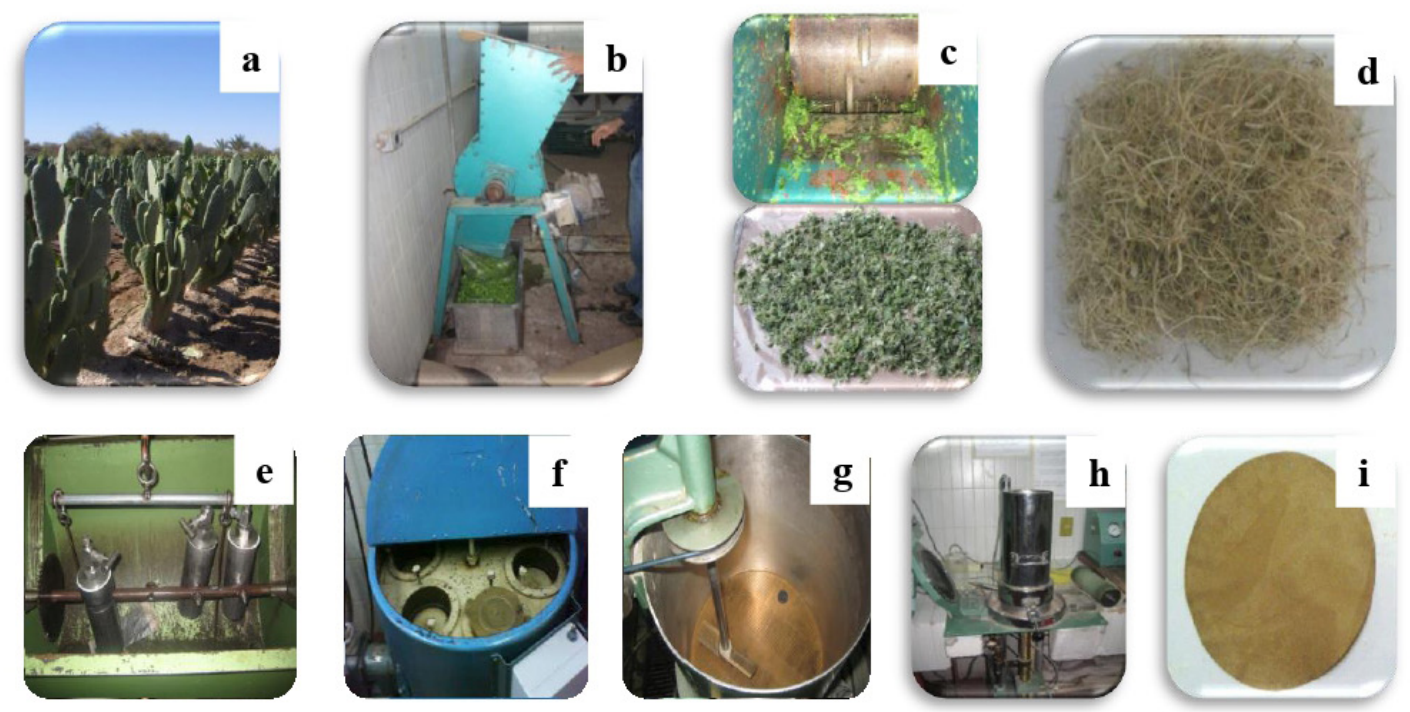

Figure 3. General process of Opuntia ficus-indica pulping. a) Raw material; b) Hammer mill c) Dry raw material; d) Fiber bundles; e) Cooking; f) Beating; g) Screening; h) Paper sheets forming; i) Final paper sheet.

Figura 3. Proceso general de despulpado de Opuntia ficus-indica. a) Obtención de la materia prima; b) Reducción de materia prima; c) Secado de materia prima; d) Obtención de haces de fibrosos; e) Cocción; f) Refinación; g) Depuración; h) Formación de hojas de papel; i) Hoja de papel.

Table 3. Cooking conditions and properties obtained from OFI waste pulp.

Tabla 3. Condiciones de cocción y propiedades de la pulpa obtenida residuos de OFI.

\begin{tabular}{lccccccc}
\hline Treatment & Temperature, ${ }^{\circ} \mathbf{C}$ & Time, $\mathbf{m i n}$ & $\mathbf{N a O H}, \%$ & Screening yield, \% & Reject, \% & Total yield, \% & Kappa number \\
\hline 1 & 160 & 60 & 20 & $24.0 \pm 0.9$ & $21.0 \pm 4.0^{\mathrm{b}}$ & $45.0 \pm 4.9$ & $70.0 \pm 0.4^{\mathrm{a}}$ \\
\hline 2 & 160 & 60 & 28 & $41.8 \pm 2.8$ & $0.2 \pm 0.3^{\mathrm{a}}$ & $42.0 \pm 2.5$ & $59.6 \pm 2.1^{\mathrm{ab}}$ \\
\hline 3 & 160 & 120 & 20 & $19.7 \pm 1.3$ & $23.3 \pm 2.2^{\mathrm{b}}$ & $43.0 \pm 0.8$ & $53.0 \pm 1.9^{\mathrm{bc}}$ \\
4 & 160 & 120 & 28 & $20.6 \pm 0.4$ & $21.5 \pm 1.1^{\mathrm{b}}$ & $42.1 \pm 1.5$ & $47.1 \pm 0.3^{\mathrm{bd}}$ \\
\hline 5 & 175 & 60 & 20 & $18.2 \pm 4.6$ & $22.1 \pm 3.9^{\mathrm{b}}$ & $40.4 \pm 0.7$ & $37.3 \pm 0.2^{\mathrm{de}}$ \\
\hline 6 & 175 & 60 & 28 & $36.3 \pm 7.7$ & $0.1 \pm 0.0^{\mathrm{a}}$ & $36.4 \pm 7.6$ & $38.5 \pm 8.8^{\mathrm{df}}$ \\
\hline 7 & 175 & 120 & 20 & $14.0 \pm 4.8$ & $29.5 \pm 1.5^{\mathrm{b}}$ & $43.5 \pm 6.3$ & $42.4 \pm 1.7^{\mathrm{cdg}}$ \\
\hline 8 & 175 & 120 & 28 & $32.1 \pm 1.6$ & $0.2 \pm 0.0^{\mathrm{a}}$ & $32.2 \pm 1.6$ & $29.6 \pm 1.7^{\mathrm{efg}}$ \\
\hline
\end{tabular}

Results are presented as mean \pm SD of two replicates.

Means within a column followed by different letters differ significantly at $p<0.05$. 
The Kappa number ranged between 29.6 and 70.0 for all the pulp treatments. This number expresses the lignin content in the pulp and how easy it is bleached. Severe pulping conditions favored the Kappa number. The pulp with the highest Kappa number was obtained with $20 \%$ $\mathrm{NaOH}, 60$ min and $160^{\circ} \mathrm{C}$ (treatment 1). On the other hand, the pulp with the lowest Kappa number was obtained with treatments 5 and 8, which consisted of $20 \% \mathrm{NaOH}$ for $60 \mathrm{~min}$ at $175^{\circ} \mathrm{C}$, and $28 \% \mathrm{NaOH}$ for $120 \mathrm{~min}$ at $175^{\circ} \mathrm{C}$, respectively. Kappa numbers for both treatments were transformed into residual lignin giving 4.8 and $3.8 \%$ for treatments 5 and 8 , respectively. Both values are in the range (2-5\%) suggested for materials suitable for bleaching pulps (García-Hortal et al., 2008). Nevertheless, the lignin residual value for the pulp of treatment 5 was close to the upper limit and the rejects were high. On the other hand, the lignin residual value for the pulp of treatment 8 was at good level and the rejects were low. According to these results, the best conditions for pulping were $28 \% \mathrm{NaOH}$ for 120 min at $175^{\circ} \mathrm{C}$ (treatment 8). In conclusion, OFI waste fibers exposed with a soda pulping process (28\% $\mathrm{NaOH}, 175^{\circ} \mathrm{C}$ and $120 \mathrm{~min}$ ) produced pulps with a low Kappa number.

\section{Characterization of paper sheets}

Figure $3 \mathrm{i}$ exhibits a paper sheet of OFI waste pulp and Table 4 shows the paper sheet properties produced with the OFI waste pulp. Tensile strength index is a property that is influenced by three factors: fiber length, fiber strength and fiber bonding ability. Generally, softwood pulps have a higher tensile index than hardwood ones, and non-wood pulps have a low tensile strength index in comparison with softwood and hardwood pulp. In agreement with this, tensile strength index for $\mathrm{OFI}$ waste pulp $(36.0 \pm 5.0 \mathrm{Nm} / \mathrm{g})$ is low in comparison with that of pine $(76.1 \mathrm{Nm} / \mathrm{g})$ and poplar $(40.40$ $\mathrm{Nm} / \mathrm{g}$ ) pulps. However, it is in the same range of pulp derived from non-wood fibers like sugarcane bagasse $(38.2 \mathrm{Nm} / \mathrm{g})$, rice straw $(41.7 \mathrm{Nm} / \mathrm{g})$ and sunflower stalks $(43.64 \mathrm{Nm} / \mathrm{g})$ (Khristova et al., 2006; Fišerová and Gigac, 2011; Sarwar Jahan et al., 2012; Mazhari Mousavi et al., 2013; Danielewicz et al., 2015).

The burst index is a measure of the resistance to rupture of paper. Several authors suggest that this property is intimately related to the cell wall thickness and length of the fibers (Horn, 1974). The longer the fibers are, the greater the burst index. On the other hand, the greater the cell wall thickness of the fiber, the lower the burst index. OFI waste burst index $\left(3.2 \pm 0.4 \mathrm{kPam}^{2} / \mathrm{g}\right)$ is higher than the reported by Mannai et al. (2018) for OFI papers $\left(5.8 \mathrm{kPam}^{2} / \mathrm{g}\right)$. However, the fibers $(0.76 \mathrm{~mm})$ used for Mannai et al (2018) were shorter than the fibers used for us on this research. This difference could be influenced by the conditions of the pulping process. The OFI waste burst index is in the range published for wood and non-wood papers sheets like Agave tequilana (2.2 $\left.\mathrm{kPam}^{2} / \mathrm{g}\right)$, rapeseed straw $\left(3.42 \mathrm{kPam}^{2} / \mathrm{g}\right)$, sunflower stalks $\left(2.89 \mathrm{kPam}^{2} / \mathrm{g}\right)$, kenaf $\left(3.2 \mathrm{kPam}^{2} / \mathrm{g}\right)$, pine $\left(2.6 \mathrm{kPam}^{2} / \mathrm{g}\right)$ and poplar $\left(2.3 \mathrm{kPam}^{2} / \mathrm{g}\right.$ ) (Khristova et al., 1998; Iñiguez-Covar-
Table 4. Properties of paper sheets obtained from OFI waste pulp.

Tabla 4. Propiedades de las hojas de papel obtenidas a partir de pulpa residual de OFI.

\begin{tabular}{lc}
\hline Property & Value \\
\hline Tensile index, Nm/g & $36.0 \pm 5.0$ \\
\hline Stretch, \% & $1.7 \pm 0.3$ \\
\hline Breaking length, $\mathrm{km}$ & $3.7 \pm 0.5$ \\
\hline Burst index, $\mathrm{KPa} . \mathrm{m}^{2} / \mathrm{g}$ & $3.2 \pm 0.4$ \\
\hline Tear index, $\mathrm{mN} . \mathrm{m}^{2} / \mathrm{g}$ & $7.3 \pm 0.0$ \\
\hline Folding endurance, times & 166 \\
\hline Gurley's porosity, s & $>120$ \\
\hline
\end{tabular}

Results are presented as mean \pm SD of ten replicates

rubias et al., 2001; Boeva et al., 2007; Villar et al., 2009; Koray Gulsoy, and Eroglu 2011; Mazhari Mousavi et al., 2013). Tear index reflects the work needed to tear paper and it has a relationship with the length of the fibers (Shmulsky and Jones, 2011). OFI waste paper sheets presented a tear index lower than the reported for $\mathrm{OFI}$ cladodes sheets $\left(12 \mathrm{mNm}^{2} / \mathrm{g}\right)$ and OFI trunks sheets $\left(19.2 \mathrm{mNm}^{2} / \mathrm{g}\right)$. These differences can be attributed to OFI fiber length, OFI cladodes fibers were 0.74 $\mathrm{mm}$ and $\mathrm{OFI}$ trunks fibers were $0.76 \mathrm{~mm}$ (Mannai et al., 2016; Mannai et al., 2018). OFI waste paper sheets tear index was in the range published for paper sheets of wood and non-wood fibers like Agave tequilana $(6.9 \mathrm{mNm} / \mathrm{g})$, sugarcane bagasse $\left(6.3 \mathrm{mNm}^{2} / \mathrm{g}\right)$, and poplar $\left(4 \mathrm{mNm}^{2} / \mathrm{g}\right)$ (Iñiguez-Covarrubias et al., 2001; Khristova et al., 2006). This result is consistent with the reported for paper made with a fiber of similar length as that of rapeseed straw $\left(1.03 \mathrm{~mm} ; 4.90 \mathrm{mNm}^{2} / \mathrm{g}\right)$ and sunflower stalks $\left(1.27 \mathrm{~mm} ; 6.0 \mathrm{mNm}^{2} / \mathrm{g}\right.$ ) (Khristova et al., 1998; Ai and Tschirner, 2010; Mazhari Mousavi et al., 2013). However, Mannai et al. (2018) indicated a higher tear index $\left(12 \mathrm{mNm}^{2} / \mathrm{g}\right)$ for OFI cladodes. The breaking length expresses the length of the paper, which would just break under its own weight. It is a measure of the resistance of paper to direct tension under specific conditions of rate of extension (Ghasemian et al., 2012). Higher values are preferred for a good quality paper. The breaking length obtained for OFI waste pulps was $3.7 \pm 0.5 \mathrm{~km}$. This value is higher than the reported for OFI cladodes paper sheets $(1.5 \mathrm{~km})$, OFI trunks paper sheets (1.9 $\mathrm{km})$, and rice straw paper sheets $(2.7 \mathrm{~km})$ but lower than the reported for Eulaliopsis binata paper sheets $(5.3 \mathrm{~km}$ ) (Tyagi et al., 2004; Rodríguez et al., 2008; Mannai et al., 2018).

Stretch reflects the capability of paper to conform a desired contour, or to resist nonuniform tensile stress and it is important in all types of papers. The stretch \% obtained for OFI waste paper sheets was higher $(1.7 \pm 0.3 \%)$ than the value reported for sheets produced with vine shoots pulp (1.49\%) and Cyanara cardunculus (1.40\%) but lower than the published data for sheets produced with rice straw (1.94-2.40 $\%$ ) and eucalyptus (3.56\%) (Gominho et al., 2001; Mutjé et al., 2005; Jiménez et al., 2007; Rodríguez et al., 2008). Oluwadere and Ashimiyu (2007) found that cell wall thickness and fiber length were the main factors which influenced the strength properties like stretch \% in paper sheets obtained from Leu- 
caena leucocephala pulp. In agreement with this finding, the lower stretch \% of sheets produced with OF/ waste pulp compared to that of sheets produced with eucalyptus pulp can be explained as follow. Although the fiber length for OFI (1.1 $\mathrm{mm}$ ) and eucalyptus $(0.93 \mathrm{~mm})$ is similar, the wall thickness is thicker for the eucalyptus fibers $(6.1 \mu \mathrm{m})$ than for OFI fibers $(4.3 \mu \mathrm{m})$ (Gominho et al., 2014). Therefore, the lower stretch $\%$ obtained for the OFI waste sheets shows its poor flexibility compared to the high flexibility reported for eucalyptus.

Folding endurance is a property that can be used as an indicator of paper durability. This property measures the capacity of paper of keeping its folding line without breaking during repeating folding. Additionally, it reflects the degree to which the paper keeps its physical properties in relation to the frequency of use (Ponce-Jiménez et al., 2002). OFI waste sheets presented a holding endurance (166 times) in the range for non-wood pulps. Folding endurance keep a positive correlation with fiber length (Ona et al., 2001). This correlation can be observed in the paper derived from OFI waste fibers with similar length, such is the case of switchgrass (folding endurance $=210 ; 0.78 \mathrm{~mm}$ fiber length), alfalfa (folding endurance $=180 ; 0.78 \mathrm{~mm}$ fiber length), Ipomea carnea (folding endurance $=128 ; 0.62 \mathrm{~mm}$ fiber length) and Cannabis sativa (folding endurance $=223 ; 1.11 \mathrm{~mm}$ fiber length) (Dutt et al., 2004; Ai and Tschirner, 2010).

Finally, regarding the porosity test, OFI waste paper sheets were not permeable to air because its pores were closed. This value is opposite to the reported for OFI cladodes (68.6\%) and OFI trunks (71.2\%) paper sheets (Mannai et al., 2016; Mannai et al., 2018). Air resistance is a property governed by internal structure (type and length of fibers, degree of hydration, orientation and compaction of the fibers, as well as the type and amount of fillers and sizing) (T-460om-16 2016). For example, paper sheet of kenaf (core fiber) had similar behavior than OFI waste paper. Kenaf paper had low air permeability, this was attributed to the fact that the fibers were small. The small size of the fibers facilitated the filling of voids in the paper sheets (Villar et al., 2009). Santos et al. (2008) reported that pulp fibers with thinner fiber walls (more collapsible), generate paper structures with lower air permeability. In general, the pulp properties of OFI waste fibers were comparable to those of wood and non-woods pulp paper like pine, rapeseed straw, sugarcane bagasse and rice straw.

The main components of paper are recycled pulp (40-43\%), chemical pulp (35-39\%), mechanical pulp (8-11\%), mineral fillers $(8-11 \%)$ and chemical products (2-3\%). The pulps come from different sources and origins. The mix of these components to form the structure of the paper allows high degrees of freedom to design a paper that satisfy the end use specifications of the product (Turrado-Saucedo et al., 2008). According with the results of this research, the stretch and tear indexes of virgin $\mathrm{OFI}$ pulp agree to those specified for paper kraft (1.5\%), bond paper $\left(7.0 \mathrm{mNm}^{2} / \mathrm{g}\right)$, and coating base paper (6.25 to 8.75) (Escoto-García, 2004; Zanuttini et al., 2008). The OFI pulp has its own properties which can be modified by mixing it with pulp from different sources to satisfy paper type specifications.

\section{CONCLUSIONS}

The intrinsic properties, chemical characteristics, and fiber morphology of Mexican OFI waste reveals that this nonwood plant can be used as a raw material for paper making. Mechanical properties of paper sheets obtained by the soda process reflect the quality of OFI fibers and the adequate conditions of processing applied (time, temperature, and active alkali). It remains to be further clarified whether our findings could be applied to the processing of different types of paper.

The use of $O F /$ waste as a raw material for papermaking shows an option to utilize this unused byproduct. Therefore, an approach with respect to the technological, economical, and commercial viability needs to be developed to enable the sustainable utilization of OFI waste for papermaking to achieve a complete valorization.

\section{FUNDING}

This research did not receive any specific grant from funding agencies in the public, commercial, or not-for-profit sectors.

\section{REFERENCES}

$A i$, J. and Tschirner, U. (2010) 'Fiber length and pulping characteristics of switchgrass, alfalfa stems, hybrid poplar and willow biomasses', Bioresource Technology, 101(1), 215221, available: http://dx.doi.org/https://doi.org/10.1016/j. biortech.2009.07.090.

Anupam, K., Sharma, A.K., Lal, P.S. and Bist, V. (2016) 'Physicochemical, morphological, and anatomical properties of plant fibers used for pulp and papermaking' in Ramawat, K. and Ahuja, M., eds., Fiber Plants Springer, Cham, 235-248.

Ashori, A., Harun, J., Raverty, W.D. and Yusoff, M.N.M. (2006) 'Chemical and morphological characteristics of Malaysian cultivated kenaf (Hibiscus cannabinus) fiber', Polymer-Plastics Technology and Engineering, 45(1), 131-134, available: http:// dx.doi.org/10.1080/03602550500373782.

Barbera, M. and Gurnari, G. (2018) 'Quality standards for recycled water: Opuntia ficus-indica as sorbent material' in Barbera, M. and Gurnari, G., eds., Wastewater Treatment and Reuse in the Food Industry Springer, Cham, 29-47.

Boeva, R., Petkova, E., Georgieva, N., Yotova, L. and Spiridonov, I. (2007) 'Utilization of a chemical-mechanical pulp with improved properties from poplar wood in the composition of packing papers', Bioresources, 2(1), 34-40.

Cheikh Rouhou, M., Abdelmoumen, S., Thomas, S., Attia, H. and Ghorbel, D. (2018) 'Use of green chemistry methods in the extraction of dietary fibers from cactus rackets (Opuntia ficus indica): Structural and microstructural studies', International Journal of Biological Macromolecules, 116, 901910, available: http://dx.doi.org/https://doi.org/10.1016/j. ijbiomac.2018.05.090.

Ciriminna, R., Chavarría-Hernández, N., Rodríguez-Hernández, A.I. and Pagliaro, M. (2019) 'Toward unfolding the bioeconomy of nopal (Opuntia spp.)', Biofuels, Bioproducts and Biorefining, 13(6), 1417-1427, available: http://dx.doi. org/10.1002/bbb.2018. 
Danielewicz, D., Surma-Ślusarska, B., Żurek, G., Martyniak, D., Kmiotek, M. and Dybka, K. (2015) 'Selected grass plants as biomass fuels and raw materials for papermaking, part II. Pulp and paper properties', Bioresources, 10(4), 8552-8564.

Del Río, J.C., Gutiérrez, A., Rodríguez, I.M., Ibarra, D. and Martínez, Á.T. (2007) 'Composition of non-woody plant lignins and cinnamic acids by Py-GC/MS, Py/TMAH and FT-IR', Journal of Analytical and Applied Pyrolysis, 79(1), 39-46, available: http:// dx.doi.org/https://doi.org/10.1016/j.jaap.2006.09.003.

Dutt, D., Upadhyaya, J., Malik, R. and Tyagi, C. (2004) 'Studies on pulp and paper-making characteristics of some indian nonwoody fibrous raw materials: Part 1', Journal of Scientific and Industrial Research, 63(January), 48-57.

Escoto-García, T. (2004) Evaluación en la calidad en pulpa, papel y cartón.

FAO (2016) 'Producción y comercio mundiales de productos forestales en 2016', Food and Agriculture Organization of the United Nations.

FAO (2017) 'Pulp and paper capacities, survey 2016-2021', Food and Agriculture Organization of the United Nations.

Fišerová, M. and Gigac, J. (2011) ‘Comparison of hardwood kraft pulp fibre characteristics and tensile strength', Cellulose Chemistry and Technology, 45(9), 627.

García-Hortal, J., Roncero, T. and Vidal, T. (2008) 'Blanqueo de pasta' in Area, M. C., ed., Panorama de la industria de celulosa y papel en Iberoamérica, Argentina: Red Iberoamericana de Docencia e Investigación en Celulosa y Papel, 561.

Ghasemian, A., Ghaffari, M. and Ashori, A. (2012) 'Strengthenhancing effect of cationic starch on mixed recycled and virgin pulps', Carbohydrate Polymers, 87(2), 1269-1274, available: $\quad$ http://dx.doi.org/https://doi.org/10.1016/j. carbpol.2011.09.010.

Gibson, A.C. (1977) 'Wood anatomy of opuntias with cylindrical to globular stems', Botanical Gazette, 138(3), 334-351.

Ginestra, G., Parker, M.L., Bennett, R.N., Robertson, J., Mandalari, G., Narbad, A., Lo Curto, R.B., Bisignano, G., Faulds, C.B. and Waldron, K.W. (2009) 'Anatomical, chemical, and biochemical characterization of cladodes from prickly pear [Opuntia ficusindica (L.) Mill.]', Journal of Agricultural and Food Chemistry, 57(21), 10323-10330, available: http://dx.doi.org/10.1021/ jf9022096.

Gominho, J., Fernandez, J. and Pereira, H. (2001) 'Cynara cardunculus L. - a new fibre crop for pulp and paper production', Industrial Crops and Products, 13(1), 1-10, available: http://dx.doi.org/https://doi.org/10.1016/S09266690(00)00044-3.

Gominho, J., Lopes, C., Lourenço, A., Simões, R. and Pereira, H. (2014) 'Eucalyptus globulus stumpwood as a raw material for pulping', Bioresources, 9(3), 4038-4049.

Gonzalo, A., Bimbela, F., Sánchez, J.L., Labidi, J., Marín, F. and Arauzo, J. (2017) `Evaluation of different agricultural residues as raw materials for pulp and paper production using a semichemical process', Journal of Cleaner Production, 156, 184-193, available: http://dx.doi.org/https://doi. org/10.1016/j.jclepro.2017.04.036.

Greco, A., Gennaro, R., Timo, A., Bonfantini, F. and Maffezzoli, A. (2013) 'A comparative study between bio-composites obtained with Opuntia ficus indica cladodes and flax fibers', Journal of Polymers and Environment, 21(4), 910-916, available: http://dx.doi.org/10.1007/s10924-013-0595-x.
Greco, A. and Maffezzoli, A. (2015) 'Rotational molding of biodegradable composites obtained with PLA reinforced by the wooden backbone of Opuntia ficus indica cladodes', Journal of Applied Polymer Science, 132(48), available: http:// dx.doi.org/10.1002/app.42447.

Gulsoy, S.K. and Ozturk, F. (2015) 'Kraft pulping properties of European black pine cone', Maderas: Ciencia y Tecnología, 17(4), 875-882, available: http://dx.doi.org/https://dx.doi. org/10.4067/S0718-221X2015005000076.

Guzmán, U., Arias, S. and Dávila, P. (2003) Catálogo de cactáceas mexicanas, Universidad Nacional Autónoma de México. Comisión Nacional para el Conocimiento y Uso de la Biodiversidad.

Herbes, C., Beuthner, C. and Ramme, I. (2018) 'Consumer attitudes towards biobased packaging - A cross-cultural comparative study', Journal of Cleaner Production, 194, 203 218, available: http://dx.doi.org/https://doi.org/10.1016/j. jclepro.2018.05.106.

Horn, R.A. (1974) Morphology of wood pulp fiber from softwoods and influence on paper strength, Madison, Wisconsin, USA: United Statetes Department of Agriculture.

IEA (2017) 'International Energy Outlook 2017', International Energy Agency, Report Number: DOE/EIA-0484 (2017).

Inglese, P., Mondragon Jacobo, C., Nefzaoui, A. and Sáenz, C. (2018) Ecología del cultivo, manejo y usos del nopal, Roma: La Organización de las Naciones Unidas para la Alimentación y la Agricultura. Centro Internacional de Investigaciones Agrícolas en Zonas Áridas.

Iñiguez-Covarrubias, G.,Díaz-Teres, R., Sanjuan-Dueñas, R., Anzaldo-Hernández, J. and Rowell, R.M. (2001) 'Utilization of by-products from the tequila industry. Part 2: potential value of Agave tequilana Weber azul leaves', Bioresource Technology, 77(2), 101-108, available: http://dx.doi.org/ https://doi.org/10.1016/S0960-8524(00)00167-X.

Jaramillo-Flores, M.E., González-Cruz, L., Cornejo-Mazón, M., Dorantes-Alvarez, L., Gutiérrez-López, G.F. and HernándezSánchez, H. (2003) 'Effect of thermal treatment on the antioxidant activity and content of carotenoids and phenolic compounds of cactus pear cladodes (Opuntia ficus-indica)', Food Science and Technology International, 9(4), 271-278, available: http://dx.doi.org/10.1177/108201303036093.

Jiménez, L., Pérez, A., de la Torre, M.J., Moral, A. and Serrano, L. (2007) 'Characterization of vine shoots, cotton stalks, Leucaena leucocephala and Chamaecytisus proliferus, and their ethyleneglycol pulps', Bioresource Technology, 98(18), 3487-3490, available: http://dx.doi.org/https://doi. org/10.1016/j.biortech.2006.11.009.

Kaur, D., Bhardwaj, N.K. and Lohchab, R.K. (2017) 'Prospects of rice straw as a raw material for paper making', Waste Management, 60, 127-139, available: http://dx.doi.org/ https://doi.org/10.1016/j.wasman.2016.08.001.

Kaur, D., Bhardwaj, N.K. and Lohchab, R.K. (2018) 'A study on pulping of rice straw and impact of incorporation of chlorine dioxide during bleaching on pulp properties and effluents characteristics', Journal of Cleaner Production, 170, 174182, available: http://dx.doi.org/https://doi.org/10.1016/j. jclepro.2017.09.111.

Khristova, P., Gabir, S., Bentcheva, S. and Dafalla, S. (1998) 'Sodaanthraquinone pulping of sunflower stalks', Industrial Crops and Products, 9(1), 9-17, available: http://dx.doi.org/https:// doi.org/10.1016/S0926-6690(98)00008-9. 
Khristova, P., Kordsachia, O., Patt, R., Karar, I. and Khider, T. (2006) 'Environmentally friendly pulping and bleaching of bagasse', Industrial Crops and Products, 23(2), 131-139, available: http:// dx.doi.org/https://doi.org/10.1016/j.indcrop.2005.05.002.

Koray Gulsoy, S. and Eroglu, H. (2011) 'Biokraft pulping of European black pine with Ceriporiopsis subvermispora', International Biodeterioration and Biodegradation, 65(4), 644648, available: http://dx.doi.org/https://doi.org/10.1016/j. ibiod.2010.12.013.

Lee, E.H., Kim, H.J., Song, Y.S., Jin, C., Lee, K.-T., Cho, J. and Lee, Y.S. (2003) 'Constituents of the stems and fruits of Opuntia ficus-indica var.saboten', Archives of Pharmacal Research, 26(12), 1018-1023, available: http://dx.doi.org/10.1007/ BF02994752.

López, F., García, M.M., Yánez, R., Tapias, R., Fernández, M. and Díaz, M.J. (2008) 'Leucaena species valoration for biomass and paper production in 1 and 2 year harvest', Bioresource Technology, 99(11), 4846-4853, available: http://dx.doi.org/ https://doi.org/10.1016/j.biortech.2007.09.048.

Majdoub, H., Roudesli, S. and Deratani, A. (2001) 'Polysaccharides from prickly pear peel and nopals of Opuntia ficus-indica: extraction, characterization and polyelectrolyte behaviour', Polymer International, 50(5), 552-560, available: http:// dx.doi.org/10.1002/pi.665.

Malainine, M.E., Dufresne, A., Dupeyre, D., Mahrouz, M., Vuong, R. and Vignon, M.R. (2003) 'Structure and morphology of cladodes and spines of Opuntia ficus-indica. Cellulose extraction and characterisation', Carbohydrate Polymers, 51(1), 77-83, available: http://dx.doi.org/https://doi. org/10.1016/S0144-8617(02)00157-1.

Malainine, M.E., Mahrouz, M. and Dufresne, A. (2004) 'Lignocellulosic flour from cladodes of Opuntia ficus-indica reinforced poly(propylene) composites', Macromolecular Materials and Engineering, 289(10), 855-863, available: http://dx.doi.org/10.1002/mame.200400103.

Malainine, M.E., Mahrouz, M. and Dufresne, A. (2005) 'Thermoplastic nanocomposites based on cellulose microfibrils from Opuntia ficus-indica parenchyma cell', Composites Sciences and Technology, 65(10), 1520-1526, available: $\quad$ http://dx.doi.org/https://doi.org/10.1016/j. compscitech.2005.01.003.

Man, Y., Han, Y., Wang, Y., Li, J., Chen, L., Qian, Y. and Hong, M. (2018) 'Woods to goods: Water consumption analysis for papermaking industry in China', Journal of Cleaner Production, 195, 1377-1388, available: http://dx.doi.org/ https://doi.org/10.1016/j.jclepro.2018.06.026.

Mannai, F., Ammar, M., Yanez, J.G., Elaloui, E. and Moussaoui, Y. (2016) 'Cellulose fiber from Tunisian Barbary Fig "Opuntia ficus-indica" for papermaking', Cellulose, 23(3), 2061-2072, available: http://dx.doi.org/10.1007/s10570-016-0899-9.

Mannai, F., Ammar, M., Yanez, J.G., Elaloui, E. and Moussaoui, Y. (2018) 'Alkaline delignification of cactus fibres for pulp and papermaking applications', Journal of Polymers and Environment, 26(2), 798-806, available: http://dx.doi.org/ https://doi.org/10.1007/s10924-017-0968-7.

Marin-Bustamante, M.Q., Chanona-Pérez, J.J., Güemes-Vera, N., Cásarez-Santiago, R., PereaFlores, M.J., Arzate-Vázquez, I. and Calderón-Domínguez, G. (2017) 'Production and characterization of cellulose nanoparticles from nopal waste by means of high impact milling', Procedia Engineering, 200, 428-433, available: http://dx.doi.org/https://doi. org/10.1016/j.proeng.2017.07.060.

Mazhari Mousavi, S.M., Hosseini, S.Z., Resalati, H., Mahdavi, S. and Rasooly Garmaroody, E. (2013) ‘Papermaking potential of rapeseed straw, a new agricultural-based fiber source', Journal of Cleaner Production, 52, 420-424, available: http:// dx.doi.org/https://doi.org/10.1016/j.jclepro.2013.02.016.

Mulyantara, L.T., Harsono, H., Maryana, R., Jin, G., Das, A.K. and Ohi, H. (2017)‘'Properties of thermomechanical pulps derived from sugarcane bagasse and oil palm empty fruit bunches', Industrial Crops and Products, 98, 139-145, available: http:// dx.doi.org/https://doi.org/10.1016/j.indcrop.2016.11.003.

Mutjé, P., Pèlach, M.A., Vilaseca, F., García, J.C. and Jiménez, L. (2005) 'A comparative study of the effect of refining on organosolv pulp from olive trimmings and kraft pulp from eucalyptus wood', Bioresource Technology, 96(10), 11251129, available: http://dx.doi.org/https://doi.org/10.1016/j. biortech.2004.10.001.

Nobel, P.S. and Bobich, E.G. (2002) 'Enviromental Biology' in Nobel, P. S., ed., Cacti Biology and Uses, United States of America: University of California, 57-74.

Oluwadare, A.O. and Ashimiyu, O.S. (2007) 'The relationship between fiber characteristics and pulp-sheet properties of Leucaena leucocephala (lam.) de Wit', Middle-East Journal of Scientific Research, 2(2), 63-68.

Ona, T., Sonoda, T., Ito, K., Shibata, M., Tamai, Y., Kojima, Y., Ohshima, J., Yokota, S. and Yoshizawa, N. (2001)`Investigation of relationships between cell and pulp properties in Eucalyptus by examination of within-tree property variations', Wood Science and Technology, 35(3), 229-243, available: http://dx.doi.org/10.1007/s002260100090.

Ortega-Baes, P., Sühring, S., Sajama, J., Sotola, E., Alonso-Pedano, M., Bravo, S. and Godínez-Alvarez, H. (2010) 'Diversity and conservation in the cactus family' in Ramawat, K. G., ed., Desert plants: biology and biotechnology, Berlin, Heidelberg: Springer Berlin Heidelberg, 157-173.

Ouhammou, M., Lahnine, L., Mghazli, S., Hidar, N., Bouchdoug, M., Jaouad, A., Mandi, L. and Mahrouz, M. (2017) 'Valorisation of cellulosic waste basic cactus to prepare activated carbon', Journal of the Saudi Society of Agricultural Sciences, available: $\quad$ http://dx.doi.org/https://doi.org/10.1016/j. jssas.2017.03.003.

Ponce-Jiménez, M.D.P., Toral, F.A.L. and Fornue, E.D. (2002) 'Antifungal protection and sizing of paper with chitosan saltsand cellulose ethers. Part 1, physical effects', Journal of the American Institute for Conservation, 41(3), 243-254.

Qiu, Y., Chen, Y., Pei, Y., Matsuda, H. and Yoshikawa, M. (2002) 'Constituents with radical scavenging effect from " Opuntia dillenii ": structures of new alpha-pyrones and flavonol glycoside', Chemical and Pharmaceutical Bulletin, 50(11), 1507-1510, available: http://dx.doi.org/10.1248/ cpb.50.1507.

Qiu, Y.K., Zhao, Y.Y., Dou, D.Q., Xu, B.X. and Liu, K. (2007) 'Two new a-pyrones and other components from the cladodes of Opuntia dillenii', Archives of Pharmacal Research, 30(6), 665669, available: http://dx.doi.org/10.1007/BF02977624.

Rainey, T.J. and Covey, G. (2016) 'Pulp and paper production from sugarcane bagasse' in O'Hara, I. M. and Mundree, S. G., eds., Sugarcane-based Biofuels and Bioproducts, United States of America: John Wiley \& Sons, 259-280.

Rodriguez-Felix, A. and Cantwell, M. (1988) 'Developmental changes in composition and quality of prickly pear cactus cladodes (nopalitos)', Plant Foods for Human Nutrition, 38(1), 83-93, available: http://dx.doi.org/10.1007/BF01092314. 
Rodríguez, A., Moral, A., Serrano, L., Labidi, J. and Jiménez, L. (2008) 'Rice straw pulp obtained by using various methods', Bioresource Technology, 99(8), 2881-2886, available: http:// dx.doi.org/https://doi.org/10.1016/j.biortech.2007.06.003.

Rodríguez, A., Sánchez, R., Requejo, A. and Ferrer, A. (2010) 'Feasibility of rice straw as a raw material for the production of soda cellulose pulp', Journal of Cleaner Production, 18(10), 1084-1091, available: http://dx.doi.org/https://doi. org/10.1016/j.jclepro.2010.03.011.

Rodríguez-Garcia, M.E., de Lira, C., Hernández-Becerra, E., Cornejo-Villegas, M.A., Palacios-Fonseca, A.J., Rojas-Molina, I., Reynoso, R., Quintero, L.C., Del-Real, A., Zepeda, T.A. and Muñoz-Torres, C. (2007) 'Physicochemical characterization of nopal pads (Opuntia ficus indica) and dry vacuum nopal powders as a function of the maturation', Plant Foods for Human Nutrition, 62(3), 107-112, available: http://dx.doi. org/10.1007/s11130-007-0049-5.

Rudi, H., Resalati, H., Eshkiki, R.B. and Kermanian, H. (2016) 'Sunflower stalk neutral sulfite semi-chemical pulp: an alternative fiber source for production of fluting paper', Journal of Cleaner Production, 127, 562-566, available: http:// dx.doi.org/https://doi.org/10.1016/j.jclepro.2016.04.049.

San, H.P., Long, L.K., Zhang, C.Z., Hui, T.C., Seng, W.Y., Lin, F.S., Hun, A.T. and Fong, W.K. (2016) 'Anatomical features, fiber morphological, physical and mechanical properties of three years old new hybrid Paulownia: green Paulownia', Research Journal of Foresty, 10(1), 30-35, available: http://dx.doi. org/10.3923/rjf.2016.30.35.

Santos, A.J.A., Anjos, O. and Simoes, R. (2008) 'Influence of kraft cooking conditions on the pulp quality of Eucalyptus globulus', Appita Technology, Innovation, Manufacturing, Environment, 61(2), 148.

Sarwar Jahan, M., Shamsuzzaman, M., Rahman, M.M., Iqbal Moeiz, S.M. and Ni, Y. (2012) 'Effect of pre-extraction on soda-anthraquinone (AQ) pulping of rice straw', Industrial Cropd and Products, 37(1), 164-169, available: http://dx.doi. org/https://doi.org/10.1016/j.indcrop.2011.11.035.

Shmulsky, R. and Jones, P.D. (2011) Forest products and wood science: an introduction, Pondicherry, India: John Wiley \& Sons.

SIAP (2017) 'Anuario Estadiístico de la Producción Agrícola'.

Stintzing, F.C. and Carle, R. (2005) 'Cactus stems (Opuntia spp.): A review on their chemistry, technology, and uses', Molecular Nutrition Food Research, 49(2), 175-194, available: http:// dx.doi.org/10.1002/mnfr.200400071.

Sun, M., Wang, Y. and Shi, L. (2018) 'Environmental performance of straw-based pulp making: a life cycle perspective', Science of The Total Environment, 616-617, 753-762, available: http:// dx.doi.org/https://doi.org/10.1016/j.scitotenv.2017.10.250.
T-460-om-16 (2016) 'Air resistance of paper (Gurley method)', TAPPI.

Turrado-Saucedo, J., Saucedo-Corona, A., Iñiguez-Covarrubias, G., López-Dellamary, F., Pérez-Ramos, S., Villar-Guatirrez, J. and Mutjé-Pujol, P. (2008) 'Tecnología en la fabricación de papel' in Area, M., ed., Panorama de la industria de celulosa y papel en Iberoamérica, Argentina: Red Iberoamericana de Docencia e Investigación en Celulosa y Papel, 561.

Tyagi, C.H., Dutt, D. and Pokharel, D. (2004) 'Studies on soda and soda-AQ pulping of Eulaliopsis binata', Indian Journal of Chemical Technology, 11(1), 127-134, available: http://dx.doi. org/http://nopr.niscair.res.in/handle/123456789/9494.

Villar, J.C., Revilla, E., Gómez, N., Carbajo, J.M. and Simón, J.L. (2009) 'Improving the use of kenaf for kraft pulping by using mixtures of bast and core fibers', Industrial Crops and Products, 29(2-3), 301-307, available: http://dx.doi.org/ https://doi.org/10.1016/j.indcrop.2008.06.002.

Vishali, S. and Karthikeyan, R. (2015) 'Cactus Opuntia ficus-indica: an eco-friendly alternative coagulant in the treatment of paint effluent', Desalination and Water Treatment, 56(6), 1489-1497, available: http://dx.doi.org/10.1080/19443994. 2014.945487.

Wang, Y., Yang, X., Sun, M., Ma, L., Li, X. and Shi, L. (2016)'Estimating carbon emissions from the pulp and paper industry: a case study', Applied Energy, 184, 779-789, available: http://dx.doi. org/https://doi.org/10.1016/j.apenergy.2016.05.026.

Yang, L., Lu, M., Carl, S., Mayer, J.A., Cushman, J.C., Tian, E. and Lin, H. (2015) 'Biomass characterization of Agave and Opuntia as potential biofuel feedstocks', Biomass and Bioenergergy, 76, 43-53, available: http://dx.doi.org/https://doi.org/10.1016/j. biombioe.2015.03.004.

Zanuttini, M., Antúnez, C., Clemente, A., Torres, A., Ferreira, P. and Mochiutii, P. (2008) 'Propiedades del papel' in Area, M., ed. Panorama de la industria de celulosa y papel en Iberoamérica, Argentina: Red Iberoamericana de Docencia e Investigación en Celulosa y Papel, 561.

Zhao, X.-B., Wang, L. and Liu, D.-H. (2008) 'Peracetic acid pretreatment of sugarcane bagasse for enzymatic hydrolysis: a continued work', J Chem Technol Biot, 83(6), 950-956, available: http://dx.doi.org/10.1002/jctb.1889.

Zhong, X.-K., Jin, X., Lai, F.-Y., Lin, Q.-S. and Jiang, J.-G. (2010) 'Chemical analysis and antioxidant activities in vitro of polysaccharide extracted from Opuntia ficus indica Mill. cultivated in China', Carbohyd Polym, 82(3), 722-727, available: $\quad$ http://dx.doi.org/https://doi.org/10.1016/j. carbpol.2010.05.042. 